Ayşe Hümeyra Taşkın Kafa $\odot$
Mürşit Hasbek $\odot$
Cem Çelik $\odot$

Mustafa Zahir Bakıcı ๑

\title{
Resistance to Primary Anti-Tuberculosis Drugs \\ Between 2011-2018 in Sivas Cumhuriyet \\ University Faculty of Medicine Hospital
}

öz

Insanlık tarihi kadar eski bir hastalık olan tüberküloz hala güncelliğini koruyan önemli bir sağlık problemidir. Etkili antitüberküloz ilaçların keşfiyle tedavisinde önemli mesafe alınmış olmasına karşın, çeşitli nedenlerle dünya çapında halen önemli bir morbidite ve mortalite sebebi olarak önemini korumaktadır.

Çalışmamızda Ocak 2011-Aralık 2018 yılları arasında Sivas Cumhuriyet Üniversitesi Uygulama ve Arastırma Hastanesi Mikrobiyoloji Laboratuvarı'na gönderilen klinik örneklerden izole edilen 198 adet Mycobacterium tuberculosis kompleks (MTBK) suşunun primer anti-tüberküloz ilaçlara (izoniyazid, rifampisin, etambutol ve streptomisin) duyarlılık durumları laboratuvar veri kayıt sisteminden geriye dönük olarak incelenmiștir.

Çalışmamızda belirtilen tarihler arasında her biri farklı hastaya ait olan klinik örneklerden 198 adet MTBK izole edilmiştir. Bu suşların 179'unun (\% 90.4) her dört antibiyotiğe duyarlı olduğu görülürken, 19 (\% 9.6) izolatta direnç saptanmıştır. Dirençli örneklerin 15'inde tek ilaca, ikisinde iki ilaca, ikisinde üç ilaca karşı direnç tespit edilmiștir. İolatların \% 9.6'sının en az bir ilaca dirençli olduğu saptanmıştır. Primer tüberküloz ilaçları olan izoniyazid, rifampisin, etambutol ve streptomisine karşı tek başına direnç sırası ile \% 3.5, \% 0, \% 3 ve \% 1 olarak tespit edilmiştir. Birden fazla ilaca dirençli suş sayısı hem çoklu ilaca dirençli (ÇiD), hem de çiD dışı izolatlar için \% 1 olarak bulunmuştur.

MTBK ilaç direncinin ortaya konulduğu çalışmaların ülke genelinde, farklı bölgeleri içerecek şekilde periyodik olarak yapılması direncin güncel durumu ile ilgili değerli veriler sunmaktadır. Güncel direnç verilerinin analiz edilmesi tüberküloz kontrol programlarının gözden geçirilmesine katkı sunabilir.

Anahtar kelimeler: antitüberküloz ilaç, çoklu ilaca dirençli tüberküloz, Mycobacterium tuberculosis kompleks, tüberküloz

\section{ABSTRACT}

Tuberculosis, a disease as old as the history of humanity, is an important health problem that is still up to date. Although there has been significant progress in treatment of tuberculosis along with the discovery of effective antituberculosis drugs, it still maintains its importance as an important cause of morbidity and mortality for various reasons across the world.

In our study, the susceptibilities of 198 Mycobacterium tuberculosis complex (MTBC) strains isolated from clinical samples sent to the Microbiology Laboratory of Sivas Cumhuriyet University Application and Research Hospital between January 2011 and December 2018 against primary antituberculosis drugs (isoniazid, rifampicin, ethambutol, and streptomycin) were examined retrospectively from the laboratory data recording system.

In our study, 198 MTBC strains were isolated from the clinical samples belonging to different patients between the dates specified. While 179 (90.4\%) of these strains were susceptible to all four antibiotics, resistance was detected in a total of 19 (9.6\%) samples. Resistance to a single drug, resistance to two drugs, and resistance to three drugs were found in 15, two, and two of the resistant strains, respectively. It was determined that $9.6 \%$ of the isolates were resistant to at least one drug. Single resistance to isoniazid, rifampicin, ethambutol, and streptomycin, which are primary tuberculosis drugs, were $3.5 \%, 0 \%, 3 \%$, and 1\%, respectively. The number of strains resistant to multiple drugs was $1 \%$ for both multidrug-resistant (MDR) and non-MDR isolates. Studies revealing MTBC drug resistance which are carried out periodically across the country including different regions, provide valuable data on the current status of resistance. The analysis of current resistance data may contribute to the review of tuberculosis control programs.

Keywords: antituberculosis drugs, multidrug resistant tuberculosis, Mycobacterium tuberculosis complex, tuberculosis

(C) Telif hakkı Antibiyotik ve Kemoterapi (ANKEM) Derneği'ne aittir. Logos Tıp Yayıncılık tarafindan yayınlanmaktadır. Bu dergide yayınlanan bütün makaleler Creative Commons Atff-Gayri Ticari 4.0 Uluslararası Lisansı ile lisanslanmıştır.

(Dopyright Society of Antimicrobial Chemotherapy. This journal published by Logos Medical Publishing.

Licenced by Creative Commons Attribution-NonCommercial 4.0 International (CC BY-NC 4.0)
Alındığı tarih: 03.05.2019

Kabul tarihi: 28.08.2019

Yayın tarihi: 30.12 .2019

Ayşe Hümeyra Taşkın Kafa Sivas Cumhuriyet Üniversitesi Tıp Fak. Tıbbi Mikrobiyoloji Anabilim Dalı Sivas - Türkiye

ahtaskin@cumhuriyet.edu.tr ORCID: 0000-0002-7282-4928

M. Hasbek 0000-0002-5217-8607 C. Celik 0000-0002-7141-5874

M. Z. Bakıcı 0000-0003-3823-0007 Sivas Cumhuriyet Üniversitesi Tıp Fak. Tıbbi Mikrobiyoloji Anabilim Dalı Sivas - Türkiye 


\section{GiRiş}

Tarihi çok eski yıllara dayanan bir enfeksiyon hastalığı olan tüberküloz (TB), farklı nedenlerle araştırmacıların ilgi odağı olmuş ve hala güncelliğini koruyan bir halk sağ lığı sorunudur. Hastalığın etken bakterisi Mycobacterium tuberculosis kompleks (MTBK), uzun yıllardır tedavi edilebilir olmasına rağmen, oldukça bulaşıcı ve yetişkin yaşamını ciddi ölçüde etkileyen önemli bir patojendir. Bu patojen hava yoluyla, kontamine damlacık çekirdeklerinin solunması ile insandan insana bulaşabilmektedir ${ }^{(13,14)}$.

Yeni bir konakçıya girdikten sonra, MTBK aktif bir enfeksiyona yol açabilir veya gizli kalabilir. Özellikle latent TB'lu insan immün yetmezlik virüsü (HIV) pozitif olan bireyler gibi bağışıklık sistemi düşük kişilerde tüberküloz reaktive olarak hastalık tablosunu alevlendirebilir. Bu nedenle TB, HIV bulaşmış bireylerde oldukça önemlidir. HIV enfeksiyonunda mortalitenin üçte biri TB nedeniyledir ${ }^{(20)}$.

Dünya genelinde 2017 yılında, tahmini ortalama 10 milyon kişiye TB bulaşmış ve 1.3 milyon kişinin bu hastalıktan hayatını kaybettiği bildirilmiştir. Bulaş gözlenen hastaların 5.8 milyonu erkek, 3.2 milyonu kadın ve bir milyonu çocuklardan oluşmaktadır. Tüm ülkelerde farklı yaş gruplarında TB vakası görülmekte ancak, bu hastaların \% 90'nını yetişkin (15 yaş ve üstü) kişiler oluşturmaktadır ${ }^{(23)}$.

Günümüzde, tüberkülozun tedavisi, aktif M.tuberculosis'in ortadan kaldırımasını sağlamak ve hayatta kalan bakterilerde antibiyotik direnci gelişmesini önlemek için uzun süre boyunca çoklu bakterisid ve sterilize edici ilaçların verilmesini gerektirir ${ }^{(7)}$.

Duyarlı MTBK ile enfekte hastalar altı ay boyunca dört ilaçtan oluşan standart rejimin uygulanmasıyla tedavi edilirler: izoniyazid (INH), rifampisin (RIF), etambutol (ETM) ve streptomisin (SM). Dünya Sağlık Örgütü (DSÖ=WHO), iki önemli birinci basamak ilaçlarından olan izoniazid ve rifampine karşı dirençli MTBK'yı çoklu ilaca dirençli TB (ÇiD-TB) olarak tanımlamışı( ${ }^{(6)}$.

TB'nin mevcut tedavilerindeki düşük etkinlik, yüksek toksisite (hepatotoksisite), uzun süreli tedavi, tedaviye uyumsuzluk ve beraberinde çoklu ilaç direnci (ÇiD) ile yaygın ilaç direnci (YID=XDR) gibi nedenlerden dolayı mortalite hala devam eden bir sorundur. Gelişmiş ülkeler bu sorunu kısmen çözmüş olmasına karşın gelişmekte olan ve gelişmemiş ülkelerde hastalık halen tehlikeli boyutlarda bir halk sağlığı krizi olarak devam etmektedir ${ }^{(7,17)}$.

Bakteriyel izolatların antibiyotiklere karşı geliştirdiği direnç oranları coğrafi bölgelere göre değişmekte hatta aynı bölgede dahi zaman içerisinde farklılıklar göstermektedir. O sebeple bu tür epidemiyolojik çalışmalar patojen insidansındaki ve antimikrobiyal dirençteki değişimlerin belirlenmesine olanak sağlayan önemli bilgiler sunmaktadır. Ayrıca antimikrobiyal direncin kontrolüne yönelik yaklaşımların oluşturulması ve revize edilmesi yine klinisyenlere uygun ampirik tedavi modelleri konusunda yardımcı olması bakımından önemlidir. $\mathrm{Bu}$ sebeple bu çalışmada, Sivas Cumhuriyet Üniversitesi Tıp Fakültesi Hastanesi'nde 2011-2018 yılları içerisinde hastalardan elde edilen MTBK izolatlarının antitüberküloz ilaçlara karşı direnç oranlarının tespit edilmesi ve yıllar arasındaki direnç durumlarının değişiminin araştırıması amaçlanmıştır.

\section{GEREÇ VE YÖNTEM}

Çalışmamızda Ocak 2011-Aralık 2018 yılları arasında Sivas Cumhuriyet Üniversitesi Uygulama ve Araştırma Hastanesi Mikrobiyoloji Laboratuvarı'na gönderilen klinik örneklerden izole edilen 198 adet MTBK suşunun primer anti-tüberküloz ilaçlara (INH, RIF, ETM ve SM) $)^{(9)}$ duyarlılık durumları laboratuvar veri kayıt sisteminden geriye dönük olarak araştırılmıştır. Hastalıklar ile ilgili en güvenilir veri kaynaklarından birisi kayıtlardır. C.Ü Tıp Fakültesi Araştırma ve Uygulama Hastanesi'nde tüm kayıtların işlendiği merkezi bir kayıt sistemi bulunmaktadır. Bu nedenle verilerimiz bu kayıt sistemine göre belirlenmiştir ${ }^{(18)}$.

Laboratuvarımıza gönderilen örneklerden balgam, abse, bronşial lavaj gibi klinik örnekler $\mathrm{N}$-asetil-L-sistein ve sodyum hidroksit (NALC ve $\mathrm{NaOH}$ ) kullanılarak homojenizasyon ve dekontaminasyon işleminden geçirildikten sonra; aseptik koşullarda alındığı kabul edilen beyin omurilik 
A. H. Taşkın Kafa, Sivas Cumhuriyet Üniversitesi Tıp Fakültesi Hastanesi'nde 2011-2018 Yılları Arasında Primer Antitüberküloz Illaçlara Direnç Durumu

sıVısı, steril vücut sıvıları gibi örnekler ise dekontamine edilmeden direkt işleme alınmışııı(21). Tüm örnekler paralel olarak Löwenstein Jensen katı besiyerine ve BACTEC MGIT 960 (Becton Dickinson, $A B D)$ otomotize sIVı kültür tüplerine ekilmiştir. MGIT tüplerine kontaminasyonu önleme amacıyla ekimden önce $0.8 \mathrm{ml}$ PANTA (Polimiksin B, amfoterisin B, nalidiksik asit, trimetoprim, azlosilin) solüsyonu eklenmiştir. Aynı tüplere daha sonra işlemden geçirilmiş klinik örneklerden 0.5 'er ml ekilerek cihaza yüklenmiş ve 42 gün boyunca her gün örneklerin takibi yapılarak inkübasyona devam edilmiştir.

Pozitif sonuç veren tüpler aside dirençli boyama (ARB) yapılarak kontaminasyon ve pozitiflik açısından değerlendirilmiştir. MTBK ve Tüberküloz Dışı Mikobakteri (MPTT) yönünden tanımlaması pNBA (paranitro-benzoik asit) kullanılarak yapılmıştır. pNBA kullanılan tüplerde floresan saptanmaması MTBK lehine değerlendirilmiştir. MTBK olarak değerlendirilen suşların INH $(0.1 \mu \mathrm{g} / \mathrm{ml})$, RIF $(1.0 \mu \mathrm{g} /$ $\mathrm{ml})$, ETM $(5.0 \mu \mathrm{g} / \mathrm{ml})$ ve SM $(1.0 \mu \mathrm{g} / \mathrm{ml})$ antitüberküloz ilaçlara karşı gelişen duyarlıık testleri üretici firmanın önerileri doğrultusunda BACTEC MGIT 960 (Becton Dickinson, Sparks, MD, USA) sistemi ile kullanılarak araştırılmıştır ${ }^{(2)}$. İstatistiksel analizler SPSS 25.0 programına yüklenerek verilerin frekans dağılımları yapılmış ve sonuçlar sayı ve yüzde şeklinde belirtilmiştir.
Tablo 1. MTBK suşlarının izole edildiği klinik örnekler.

\begin{tabular}{lc}
\hline Örnek & $\mathbf{n}(\%)$ \\
\hline Balgam & $116(58.6)$ \\
Açlık mide suyu & $5(2.5)$ \\
Apse & $21(10.6)$ \\
Bronkoalveolar lavaj & $22(11.1)$ \\
Beyin omurilik sıvısı & $4(2.0)$ \\
Doku & $5(2.5)$ \\
Steril vücut sıvısı & $17(8.5)$ \\
Trakeal aspirat & $2(1.0)$ \\
İdrar & $6(3.0)$ \\
\hline Toplam & $198(100.0)$ \\
\hline
\end{tabular}

\section{BULGULAR}

Bu çalışmada Ocak 2011-Aralık 2018 yılları arasında Sivas Cumhuriyet Üniversitesi Uygulama ve Araştırma Hastanesi Mikrobiyoloji Laboratuvarı'na gönderilen her biri farklı hastalara ait olan klinik örneklerden 198 adet MTBK izole edilmiştir. Hastaların 79'u (\% 40) kadın, 119'u (\% 60) erkek olup, kadınların yaş ortalaması 43.09 , erkeklerin 47.44 olarak bulunmuştur.

Duyarlılık testleri yapılan MTBK örnekleri, çoğunlukla balgam kaynaklı olmakla birlikte örneklerin dağılımı Tablo 1'de verilmiştir.

MTBK olduğu belirlenen suşların 179'unun (\% 90.4) her dört antibiyotiğe duyarlı olduğu görülürken, toplam 19 (\% 9.6) örnekte direnç saptanmıştır. Dirençli örneklerin $15^{\prime}$ inde tek ilaca,

Tablo 2. 2011-2018 arasında izole edilen MTBK'nin primer antitüberküloz ilaç direnç sonuçları [n (\%)].

\begin{tabular}{|c|c|c|c|c|c|c|c|c|c|}
\hline & 2011 & 2012 & 2013 & 2014 & 2015 & 2016 & 2017 & 2018 & Toplam \\
\hline Toplam suş sayısı & 38 & 21 & 14 & 29 & 9 & 24 & 33 & 30 & $198(100.0)$ \\
\hline Tüm ilaçlara duyarlı suş & 31 & 20 & 14 & 28 & 9 & 24 & 26 & 27 & $179(90.4)$ \\
\hline Toplam dirençli suş & 7 & 1 & 0 & 1 & 0 & 0 & 7 & 3 & $19(9.6)$ \\
\hline INH & 2 & 0 & 0 & 0 & 0 & 0 & 3 & 2 & $7(3.5)$ \\
\hline RiF & 0 & 0 & 0 & 0 & 0 & 0 & 0 & 0 & $0(0)$ \\
\hline ETM & 1 & 1 & 0 & 0 & 0 & 0 & 3 & 1 & $6(3.0)$ \\
\hline SM & 2 & 0 & 0 & 0 & 0 & 0 & 0 & 0 & $2(1.0)$ \\
\hline Toplam tek ilaca direnç & 5 & 1 & 0 & 0 & 0 & 0 & 6 & 3 & $15(7.6)$ \\
\hline INH+RIF (ÇiD) & 0 & 0 & 0 & 0 & 0 & 0 & 0 & 0 & $0(0)$ \\
\hline INH+ETM & 1 & 0 & 0 & 0 & 0 & 0 & 0 & 0 & $1(0.5)$ \\
\hline $\mathrm{INH}+\mathrm{SM}$ & 0 & 0 & 0 & 0 & 0 & 0 & 1 & 0 & $1(0.5)$ \\
\hline INH+RIF+SM (ÇID) & 1 & 0 & 0 & 1 & 0 & 0 & 0 & 0 & $2(1.0)$ \\
\hline INH+RIF+SM+ETM (ÇID) & 0 & 0 & 0 & 0 & 0 & 0 & 0 & 0 & $0(0)$ \\
\hline Toplam $\geq 2$ ilaca direnç & 2 & 0 & 0 & 1 & 0 & 0 & 1 & 0 & $4(2.0)$ \\
\hline
\end{tabular}

MTBK: Mycobacterium tuberculosis kompleks, INH: Izoniazid, RIF: Rifampisin, SM: Streptomisin, ETM: Etambutol,

ÇiD: Çoklu ilaca direnc 
ikisinde iki ilaca, ikisinde üç ilaca karşı direnç tespit edilmiştir. İncelenen suşlarda gözlenen sekiz yıllık direnç oranları Tablo 2'de sunulmuştur.

\section{TARTIŞMA}

Tüberküloz, insanlık tarihi boyunca sayısız insanın hayatını kaybetmesine neden olan bir hastalıktır. Etkili antitüberküloz ilaçların keşfi TB ile ilişkili ölümlerin sayısını azaltmış, ancak; bu gelişmelere ve çabalara rağmen TB dünya çapında önemli bir morbidite ve mortalite nedeni olarak güncelliğini korumuştur. 2017 yılında dünya genelinde ortalama 10 milyon kişi TB'ye yakalanmış ve 1.3 milyon kişi bu hastalıktan hayatını kaybetmiştir ${ }^{(5,23)}$.

Tüberküloz tanısı için alınan örnekler sıklıkla balgam olmak üzere onu bronkoalveolar lavaj ve diğer örnekler takip etmektedir. Çalışmamızda örnekler incelendiğinde sırasıyla \% 58.6 ile balgam ve \% 11.1 ile bronkoalveolar lavaj gelmektedir ki bu da beklenen bir sonuç olarak değerlendirilmiştir.

Duyarlı suşlarla enfekte tüberküloz hastaları standart dört ilaç rejimini oluşturan INH, RIF, ETM ve SM'nin bir kombinasyonunun 8-9 aylık tedavi süresi ile \% 95'in üzerinde tedavi edildiği bildirilmiştir ${ }^{(8,12)}$. Bu birinci basamak terapi ilaçları etkili düşük maliyetlidir. Mevcut TB tedavilerinin temel amacı mortaliteyi en aza indirmek, hastalığın bulaş olasılığını düşürmek ve uygulanan ilaçlara karşı direnci azaltmaktır. Tedavinin yönetimindeki zafiyet ve antitüberküloz ajanlarının uygun kullanılmaması, TB ilaç direncinin ortaya çıkmasına neden olabilmektedir ${ }^{(7)}$.

İlaç direnci TB ile ilişkili ölümlerin en çok nedenlerinden biridir. DSÖ verilerine göre 2017'de dünya çapında 558,000 TB hastasının en etkili birinci basamak ilacı olan RIF'e dirençli olduğu (RR-TB) ve bunların \% 82'sinde de ek INH direnci nedeniyle çiDTB varlığının söz konusu olduğu bildirilmektedir. Hindistan (\% 24), Çin (\% 13) ve Rusya Federasyonu (\% 10), dünyanın ÇiD/RR-TB vakalarının neredeyse yarısını oluşturmaktadır. Dünya genelinde yeni TB vakalarının \% 3.5'i ve daha önce tedavi edilen vakaların \% 18'i çiD/RR-TB'dir. 2016 yılında 153,119
ÇiD / RR-TB vakası tespit edilmişken, 2017 yılında bu sayı bir miktar artarak 160,684 ÇiD/RR-TB vakasına ulaşmıştır ${ }^{(23)}$.

Dünyada veriler bu şekilde iken ülkemiz için tüberkülozun geldiği durum değerlendirildiğinde, Sağılık Bakanlığı Verem Savaşı Daire Başkanlığı 2018 raporuna göre, 2016 yılında toplam 12,417 tüberküloz hastası verem savaşı dispanserleri kayıtlarına girmiştir. Toplam olgu hızı yüz binde $16.2^{\prime}$ den yüz binde $15.6^{\prime}$ ya (-\% 4.1) düşmüştür. Toplam 12,417 hastada yeni olguların oranı \% 92.1 $(11,442$ hasta) iken önceden tedavi görmüş olguların oranı \% 7.9'dur (975 hasta). ilaç duyarlılık testi yapılan toplam 6,037 hastanın sonuçları incelendiğinde; \% 19.2'sinde $(1,161 / 6,037)$ en az bir ilaca direnç saptanmıştır. En yüksek oranda direnç \% 11.9 ile INH'a, görülmekle birlikte \% 4.2 ile RIF'e, \% 3.7 ile ETM'ye ve \% 10.6 ile SM'ye karşı ilaç direnci geliştiği kaydedilmiştir ${ }^{(22)}$.

Bizim çalışmamızda da bu verilerle uyumlu şekilde primer antitüberküloz ilaçlar içerisinde tek başına en yüksek direncin \% 3.5 ile INH'a karşı geliştiği ve incelenen suşların \% 7.6'sı tek ilaca, \% 9.6'sının ise toplamda en az bir ilaca dirençli olduğu saptanmıştır. Birden fazla ilaca dirençli suş sayısı ÇiD-dışı \% 1 ve çiD ise \% 1 oranında bulunmuştur. Çelik ve ark.'nın ${ }^{(4)}$ 2006-2010 yılları arasında ilimizde yaptıkları benzer bir çalışmada tek başına INH direnci \% 3.7, ÇiD direnci de \% 1.6 olarak bulunmuştur. Ancak en az bir ilaca karşı direnç oranı Çelik ve ark.'nın ${ }^{(4)}$ çalışmasında \% 6.9 oranında bulunurken, yine aynı bölgede yaptığımı bu çalışmada \% 9.6 ile daha yüksek bulunmuştur. Tüberküloz tedavisinde kullanılan primer ilaçların en az birisine karşı direnç ele alındığında ilimiz için yıllar içerisinde bir artış olduğunu söyleyebiliriz. Yine ilimizde Gönlügür ve ark.(10) 2004-2006 yıllları arasında yaptıkları benzer bir çalışmada ÇiD oranını \% 3.8 olarak bulmuşlardır. Çalışmamız ile kıyaslandığında ilimiz için bu oranda bir artış tespit edilmemiştir. ÇiD direncinde bir artış olmaması sevindiricidir, ancak toplam ilaç direncindeki artış TB takip ve kontrol önlemlerinin tekrar gözden geçirilmesi ve nedenlerinin araştırılması gerekliliğini 
A. H. Taşkın Kafa, Sivas Cumhuriyet Üniversitesi Tıp Fakültesi Hastanesi'nde 2011-2018 Yılları Arasında Primer Antitüberküloz İlaçlara Direnç Durumu

ortaya koymaktadır.

Ülkemizde yapılan farklı bölgelere ait çalışmalarda Özmen ve ark. ${ }^{(15)}$ en az bir antibiyotiğe dirençli suş sayısını \% 11.7, ÇiD-TB oranı \% 3.4 olarak bulduklarını bildirmişlerdir. Ülkemizde yapılan benzer çalışmalarda ÇiD-TB oranını Taşbent ve ark. ${ }^{(19)} \%$ 2.6, Güneş ve ark. ${ }^{(11)} \%$ 6.4, Perinçek ve ark. ${ }^{(16)} \%$ 2.2, Baykal ve ark. ${ }^{(1)} \% 3.4$ olarak bildirmişlerdir. Elde ettiğimiz bu sonuçlar, ülkemiz verileriyle karşılaştırıldığında hem tek ilaca direnç hem de çid oranlarımızın daha düşük olduğunu göstermektedir.

Çalıştığımız 198 pozitif MTBK suşunun 179'u (\% 90.4) uygulanan tüm antibiyotiklere karşı duyarlı bulunmuştur. illaca duyarlı TB ve ÇiD-TB için tedavi başarı oranları sırasıyla \% 85 ve \% 50'dir. çiD-TB tedavisi, 20 ay gibi uzun süreli ve maliyetli ilaç tedavisini gerektirmektedir ${ }^{(24)}$.

ÇID-TB ile enfekte olan bireylerin, önerilen standart tedavi rejimlerine olumlu yanıtı büyük ölçüde azalmaktadır. Bu durum tüberküloz kontrolüne yönelik bir tehdit olarak kabul edilmektedir ${ }^{(3)}$.

İlaca dirençli tüberküloz gelişimini engellemek için multidisipliner bir yaklaşımla sağlık sistemleri altyapısı ve kapasitesinin büyük ölçüde güçlendirilmesi gerekmektedir. Sağlık çalışanlarında, tüberküloza karşı koruyucu önlem ve stratejilerin geliştirilmesine yönelik kapsamlı eğitime ihtiyaç vardır.

Sonuç olarak, MTBK ilaç direncinin ortaya konulduğu bu tür retrospektif çalışmaların ülke genelinde, farklı bölgeleri içerecek şekilde periyodik olarak yapılması direncin güncel durumu ile ilgili değerli veriler sunmaktadır. Güncel direnç verilerinin analiz edilmesi tüberküloz kontrol programlarının gözden geçirilmesine katkı sunabilir.

Etik Kurul Onayı: S.C.Ü Girişimsel Olmayan Klinik Araştırmalar Etik Kurulu'nun onayı alınmıştır. (Tarih: 20.03.2019/ Karar No: 2019-03/01).

Çıkar Çatışması: Yazarlar tarafından herhangi bir çıkar çatışması bildirilmemiştir.

Ethics Committee Approval: The approval of the
Non-Interventional Clinical Trials Ethics Committee was obtained. (Date: 20.03.2019/Decision No: 201903/01).

Conflict of Interest: No conflict of interest was declared by the authors.

\section{KAYNAKLAR}

1. Baykal ES, Güdücüoğlu H, Yaman G, Berktaş M. Van yöresinde izole edilen Mycobacterium tuberculosis suşlarının dört farklı yöntemle antimikobakteriyel ajanlara duyarlılık tespiti. Tuberk Toraks. 2014;62(2):122-30. https://doi.org/10.5578/tt.7323

2. Becton, Dickinson and Company. BACTEC MGIT-960 SIRE kit for the antimycobacterial susceptibility testing of Mycobacterium tuberculosis Becton, Dickinson \& Company, Sparks, MD, USA. http:// legacy.bd.com/ds/technicalCenter/clsi/clsi-960sire. pdf

3. Cohen T, Jenkins HE, Lu C, McLaughlin M, Floyd K, Zignol M. On the spread and control of ÇiD-TB epidemics: an examination of trends in antituberculosis drug resistance surveillance data. Drug Resist Updat. 2014;17(4-6):105-23. https://doi.org/10.1016/j.drup.2014.10.001

4. Çelik C, Dayı F, Kaygusuz R, Bakıcı MZ. Sivas ilinde klinik örneklerden izole edilen Mycobacterium tuberculosis kompleks suşlarının primer antitüberküloz ilaçlara direnç oranları. Türk Mikrobiyol Cem Derg. 2011;41(1):37-41. https://doi:10.5222/TMCD.2011.037

5. Daniel TM. The history of tuberculosis. Respir Med. 2006;100(11):1862-70. https://doi.org/10.1016/j.rmed.2006.08.006

6. Dheda K, Gumbo T, Gandhi NR et al. Global control of tuberculosis: from extensively drug-resistant to untreatable tuberculosis. Lancet Respir Med. 2014;2(4):321-38. https://doi.org/10.1016/S2213-2600(14)70031-1

7. Dua K, Rapalli VK, Shukla SD et al. Multi-drug resistant Mycobacterium tuberculosis \& oxidative stress complexity: emerging need for novel drug delivery approaches. Biomed Pharmacother. 2018;107:1218-29. https://doi.org/10.1016/j.biopha.2018.08.101

8. East African/British Medical Research Council. Second East African/British Medical Research Council Study. Controlled clinical trial of four 6-months regimens of chemotherapy for pulmonary tuberculosis. Second report. Am Rev Respir Dis. 1976;114(3):471-5. 
9. European Center for Disease Prevention and Control/ WHO Regional Office for Europe. Tuberculosis surveillance in Europe, Stockholm (2019). https:// ecdc.europa.eu/sites/portal/files/documents/ tuberculosis-surveillance monitoring-Europe-201920_Mar_2019.pdf

10. Gönlügür $U$, Bakıcı MZ, Gönlügür $T E$, Hasbek M. Sivas ilinde anti-tüberküloz ilaçlara direnç oranları. Mikrobiyol Bul. 2007;41(3):459-63.

11. Güneş $H$, Altın R, Mutlu LC, ve ark. Tekirdağ'da Tüberkülozun Yıllar İçindeki Değişimi. Int J Basic Clin Med. 2015;3(1):20-5.

12. Hong Kong Chest Service, BMR Council. Controlled trial of 6-months and 8-months regimens in the treatment of pulmonary tuberculosis: The results up to 24 months. Tubercle. 1979;60(4):201-10. https://doi.org/10.1016/0041-3879(79)90001-1

13. Marimani $M$, Ahmad A, Duse A. The role of epigenetics, bacterial and host factors in progression of Mycobacteriumtuberculosisinfection. Tuberculosis (Edinb). 2018;113:200-14. https://doi.org/10.1016/j.tube.2018.10.009

14. Mohareer K, Asalla S, Banerjee S. Cell death at the cross roads of host-pathogen interaction in Mycobacterium tuberculosis infection. Tuberculosis (Edinb). 2018;113:99-121. https://doi.org/10.1016/j.tube.2018.09.007

15. Özmen E, Aslan A, Uçar M, Aydın H, Yılmaz A. Erzurum Bölge tüberküloz laboratuvarında izole edilen Mycobacterıum Tuberculosıs Kompleksi suşlarının primer anti-tüberküloz ilaçlara direnç oranları. ANKEM Derg. 2017;31(2):53-8. https://doi.org/10.5222/ankem.2017.053

16. Perincek G, Tabakoğlu E, Otkun M, Özdemir L, Özdemir B. Mycobacterium tuberculosis üremesi saptanan akciğer tüberkülozlu hastaların antitüberküloz ilaçlara direnç oranları. Tur Toraks Derg. 2011;12(3):111-3. https://doi.org/10.5152/ttd.2011.25

17. Shin HJ, Kwon YS. Treatment of drug susceptible pulmonary tuberculosis, Tuberc. Respir. Dis. 2015;78(3):161-7. https://doi.org/10.4046/trd.2015.78.3.161

18. Sümbüloğlu K. Sağlık alanına Özel İstatistiksel Yöntemler. Somgür Yayıncılık, Ankara, (2003).

19. Taşbent FE, Doğan M. Konya ilinde klinik örneklerden izole edilen Mycobacterium tuberculosis kompleks suşlarının birinci seçenek antitüberküloz ilaçlara direnç oranları. Türk Mikrobiyol Cem Derg. 2016;46(4):165-71. https://doi.org/10.5222/TMCD.2016.165

20. Tuyiringire N, Tusubira D, Munyampundu JP, Tolo CU, Muvunyi CM, Ogwang PE. Application of metabolomics to drug discovery and understanding the mechanisms of action of medicinal plants with anti-tuberculosis activity. Clin Transl Med. 2018;7(1):29. https://doi.org/10.1186/s40169-018-0208-3

21. T.C. Sağıık Bakanlığı Tüberküloz Tanı ve Tedavi Rehberi. Yayın No: 862, Ankara, (2011). https:// www.toraks.org.tr/uploadFiles/30102014133530tuberkuloz_tani_ve_tedavi_rehberi.pdf

22. Türkiye'de verem savaşı 2018 raporu. Ankara: T.C. Sağlık Bakanlığı Verem Savaşı Dairesi Başkanlığı, ISBN: 978-975-590-698-0 Sağıık Bakanlığı Yayın No: 1109 Erişim adresi: https://www.toraks.org.tr/ userfiles/file/Turkiyede-Verem-Savas-2018-Raporu. pdf Erişim tarihi: 20.03.2019

23. World Health Organization. Global tuberculosis report 2018. Erişim adresi: https://www.who.int/tb/ publications/global_report/en/, Erişim tarihi: 23.03.2019

24. World Health Organization. Global Tuberculosis Report 2015. Erişim adresi: https://apps.who.int/ iris/handle/10665/191102, Erişim tarihi: 24.03.2019 